\title{
The concept of «love» in the language consciousness of a Junior school student
}

\author{
N. A. Lemyaskina ${ }^{1}$
}

${ }^{1}$ Voronezh Institute of education development named after N. F. Bunakov, 54 Berezovaya Roscha str., Voronezh 394043, Russian Federation

DOI: $10.18255 / 2412-6519-2020-2-176-185$

Research Article

Full text in Russian

One of the aspects of studying and describing the language personality of a Junior school student, and in dynamics from grade 1 to 4 , is the cognitive aspect, which includes the study of the language consciousness of a child of this age, including cultural concepts relevant to the child's language picture of the world («conscience», «soul», «happiness», etc.). The article considers the emotional concept of «love», which is among the basic values of the Russian people, affecting the formation of the meaning of human life. The paper offers a brief lexicographic analysis of the word «love» (data from the philosophical, psychological, and explanatory dictionaries). The following is a description of the results of an experiment conducted among students of grades 2-4 of educational organizations in the city of Voronezh. The analysis of the received materials allows us to distinguish the following components of the concept: 1) a sense of self-sacrificing, heartfelt attachment; 2) the person who inspires this feeling; 3) inclination, addiction to something; 4) moral qualities. Based on the data of a directed associative experiment, the image and value component of the concept "love" in the language consciousness of a younger schoolboy are determined, and the age specificity of this concept is revealed. In addition, as part of the research, children were asked to Express their opinions about love in a free form. The article presents the responses of children, which clearly reflect the collective language consciousness.

Keywords: concept, a Junior high school student, love, language awareness, children's language picture of the world

INFORMATION ABOUT THE AUTHORS

\begin{tabular}{l|l} 
Lemyaskina Natalia A. & $\begin{array}{l}\text { E-mail: nlemyaskina@mail.ru } \\
\text { Doctor of Sciences in Philology, Professor, Chief research officer } \\
\text { of the Center for research activities }\end{array}$
\end{tabular}

For citation: Lemyaskina N. A. The concept of «love» in the language consciousness of a Junior school student // Social'nye i gumanitarnye znanija. 2020. Vol. 6, No 2. P. 176-185. (in Russ.)

(C) Lemyaskina N. A., 2020

This is an open access article under the CC BY-NC-ND license (http://creativecommons.org/licenses/by-nc-nd/4.0/) 


\section{Концепт «любовь» в языковом сознании младшего школьника}

\section{Н. А. Лемяскина ${ }^{1}$}

1 Воронежский институт развития образования имени Н. Ф. Бунакова, ул. Берёзовая роща, 54, Воронеж, 394043, Российская Федерация

DOI: $10.18255 / 2412-6519-2020-2-176-185$

удК 314

Научная статья

Полный текст на русском языке

Аннотация: Одним из аспектов изучения и описания языковой личности младшего школьника, причем в динамике от 1 к 4 классу, является когнитивный аспект, который включает исследование языкового сознания ребенка данного возраста, в том числе культурных концептов, актуальных для детской языковой картины мира («совесть», «душа», «счастье» и пр.). В статье рассматривается эмоциональный концепт «любовь», который входит в число базовых ценностей русского народа, влияющих на формирование смысла жизни человека. В работе предлагается краткий лексикографический анализ слова «любовь» (данные философского, психологического, толкового словарей). Далее дано описание результатов эксперимента, проведённого среди обучающихся 2-4 классов образовательных организаций города Воронежа. Анализ полученных материалов позволяет нам выделить следующие составляющие концепта: 1) чувство самоотверженной, сердечной привязанности; 2) человек, внушающий это чувство; 3) склонность, пристрастие к чему-либо; 4) моральные качества. На основе данных направленного ассоциативного эксперимента определены образная и ценностная составляющая концепта «любовь» в языковом сознании младшего школьника, выявлена возрастная специфика данного концепта. Кроме того, в рамках проводимого исследования детям было предложено в свободной форме высказать свое мнение о любви. В статье приводятся ответы детей, в которых ярко отражается коллективное языковое сознание.

Ключевые слова: концепт, младший школьник, любовь, языковое сознание, детская языковая картина мира

ИНФОРМАЦИЯ ОБ АВТОРАХ

Лемяскина Наталия

E-mail: nlemyaskina@mail.ru Александровна

Доктор филологических наук, профессор, главный научный

сотрудник Центра научно-исследовательской деятельности

Для цитирования: Лемяскина Н. А. Концепт «любовь» в языковом сознании младшего школьника // Социальные и гуманитарные знания. 2020. Том 6, № 2. С. 176-185.

(C) Лемяскина Н. А., 2020

Статья открытого доступа под лицензией CC BY-NC-ND (http://creativecommons.org/licenses/by-nc-nd/4.0/) 
В статье исследуется эмоциональный концепт «любовь», а именно возрастная специфика концепта в языковом сознании младшего школьника (учащихся 2-4 классов). Актуальность обращения к данному концепту обусловливается, во-первых, необходимостью системного представления особенностей развития языкового сознания младшего школьника в рамках изучения языковой личности ребенка данного возраста, причем в динамике от 1 к 4 классу, во-вторых, неизученностью составляющих культурных концептов (вера, надежда, любовь и др.) в плане того, как эти фрагменты реализуются в детской языковой картине мира.

Эмоциональная сфера - одна из важных составляющих внутреннего мира человека, является объектом ряда исследований, цель которых - описать разнообразие языковых средств репрезентации [1]. В отечественной лингвистике эмоциональные концепты включают в список универсальных, поскольку эмоции делают «представителей разных этносов более или менее похожими друг на друга» [2; 3; 4]. Подобные концепты относят к константам культуры. Следует отметить, что культурных концептов не так много, однако духовная культура и языковая картина мира в большой степени может быть представлена этими концептами. Концептами, в которых заложены ценности русской культуры, являются концепты «правда», «истина», «свобода», «воля», «судьба», «вера», «любовь», «совесть», «душа»и др. Культурные концепты - это ментальные сущности, в которых отражается «дух народа», что и определяет их ориентированность на духовность и «личную сферу» человека [5]. Любовь - ключевой концепт русской языковой реальности, входящий в ментальный мир человека, она подчинена законам русской культуры, имеет тесную связь с сердцем, эмоциями [6]. Таким образом, любовь - лингвокультурный эмоциональный концепт, который обладает универсальностью.

Из всех выделяемых к настоящему времени разновидностей концептов как лингвоментальных образований, отмеченных этнокультурной спецификой, возрастной параметр особо значим для «обыденных аналогов» мировоззренческих универсалий, составляющих корпус категорий практической философии [7, с. 617]. Тем более значима возрастная вариативность для таких концептов, как любовь и счастье, составляющих для большинства носителей «обыденного сознания» смысл жизни [8, с. 130].

Вариативность «концептов-универсалий» $[9$, с. 260] обусловлена различиями в наполнении их периферийной семантики в зависимости от биологических, социальных и этнических характеристик носителей определенной лингвокультуры: пола, возраста, образовательного и имущественного ценза, места жительства (город - деревня), национальной принадлежности [10, с. 81; 11; 12, с. 118], что даёт основания для выделения индивидуальных, групповых и этнических («национальных») [13, с. 268] концептов, из которых последние варьируются уже на межъязыковом и межкультурном уровне.

Как отмечают многие исследователи, лингвокультурный концепт обладает сложной многоярусной структурой, включающей различные семантические составляющие: понятийную, образную, ценностную и пр. [12, с. 103; 14 с. 41; 15, с. 48 и пр.].

Любовь как языковой образ стала привлекать внимание лингвистов относительно недавно. В исследованиях, посвященных языковым репрезентациям этого образа, как и эмоциональной сферы в целом, реализуются самые разные подходы. Ю. Д. Апресян и А. Д. Шмелев рассматривают словарные значения слова «любовь», 
в трудах В. В. Колесова и Ю. С. Степанова осуществляется историко-этимологический подход, семантико-синтаксический и дискурсивный предложен О. Н. Селиверстовой и И. В. Орловой. Другие авторы представляют компаративистский подход: С. Г. Воркачёв сопоставляет образы любви на материале английского и русского языков, Л. Е. Вильмс - немецкого и русского. Следует отметить, что лексико-семантическое поле «любовь» является предметом рассмотрения в лингвокультурологическом, лингвострановедческом, концептуальном, сопоставительном аспектах.

Упомянутые и другие работы позволяют сделать вывод о том, что способы языковой репрезентации эмоций человека (в частности, любви) исследованы достаточно полно и всесторонне, но исследования, специально посвящённые концепту «любовь» в языковом сознании младших школьников как одному из ключевых концептов, характеризующих в детской языковой картине мира внутренний мир человека, универсальные и национально-специфические языковые (семантические) интерпретации, отсутствуют, что позволяет говорить об актуальности выбранной темы.

Этот концепт относится к числу базовых ценностей русских людей [16], в которых выражены убеждения и жизненные принципы, влияющие на формирование смысла жизни человека. Именно это определяет важность изучения концепта «любовь» на этапе реализации Федерального государственного стандарта начального общего образования, так как он ориентирован на «становление личностных характеристик младшего школьника, таких как: любящий свой народ, свой край и свою Родину; уважающий и принимающий ценности семьи и общества...» $[17$, с. 5$]$. Стандарт включает требования к результатам, в том числе «к личностным, включающим ценностно-смысловые установки обучающихся, сформированность основ гражданской идентичности, чувства гордости за свою Родину, российский народ и историю России, осознание своей этнической и национальной принадлежности; формирование ценностей многонационального российского общества; становление гуманистических и демократических ценностных ориентаций» [Там же. С. 6].

Однако если ограничиться областью межличностных отношений, то любовь - это прежде всего чувство, в котором как ни в каком другом отражается двойственность человеческой природы: единство и борьба плотского и духовного, биологического и социального начал, разума и инстинкта. Эти начала присутствуют практически во всех философских концепциях любви и фиксируются в лексике многих естественных языков [16, с. 86]. Безусловно, значима возрастная вариативность для таких концептов, как любовь и счастье, составляющих для большинства носителей «обыденного сознания» смысл жизни [Там же С. 130].

Насколько нам известно, семантика возрастных изменений универсалий мировоззренческой направленности у детей исследуемого возраста объектом целенаправленного изучения еще не являлась. Доступным источником информации относительно «онтологической вариативности» концепта «любовь» остается опрос информантов-носителей современного языкового сознания.

Психологический возраст обозначает качественно своеобразную ступень онтогенетического развития, обусловленную закономерностями формирования организма, условиями жизни и воспитания и характеризуемую особыми жизненными задачами, от которых зависит развитие личности в целом и успешность перехода на следующий возрастной этап [Там же С. 131]. 
Объектом исследования нами определен эмоциональный концепт «любовь», предметом - составляющие концепта в языковом сознании младшего школьника.

Материал для исследования - данные лексикографических изданий (философского, психологического, толковых словарей), а также репрезентация лексических единиц лексико-семантического поля «любовь», отобранных с помощью психолингвистических методов. Специфика выбранного материала потребовала применения описательного, сравнительного и количественного метода, а также метода субъективных дефиниций, метода направленного ассоциативного эксперимента. Именно такие параметры описания были выбраны в качестве оптимальных при работе с концептом. Примененные методы в совокупности позволили описать релевантные черты концепта «любовь» в языковом сознании младшего школьника.

В рамках исследования определены понятийная, образная, ценностная составляющая концепта, выявлена национально-культурная и возрастная специфика исследуемого феномена.

Для определения значения лексемы любовь мы обратились к философскому, психологическому, а также к «Большому толковому словарю русского языка» Д. Н. Ушакова и «Словарю русского языка» С. И. Ожегова.

По данным философского словаря: «Любовь - чувство устремленности к единению, близости с другим человеком, другими людьми, природой, идеями, идеалами вплоть до желания слиться с ними, раствориться в них, пожертвовать собой во имя объекта своей «любви» [18]. Краткий психологический словарь дает следующее определение: «Любовь основывается на общности интересов людей, их потребностей, целей, ценностей и сопровождается сильными эмоциями, отличающимися постоянством. Кроме того, существует любовь к истине, идеалу, Родине, народу, человечеству, <..> и человек готов отказаться от личного счастья, пожертвовать своей жизнью» [19].

В Большом толковом словаре русского языка даётся определение: Любовь, любви, твор. любовью, ж. 1. только ед. Чувство привязанности, основанное на общности интересов, идеалов, на готовности отдать свои силы общему делу. Л. к Родине. // такое же чувство, основанное на взаимном расположении, симпатии, близости. Братская л. Л. к людям. // такое же чувство, основанное на инстинкте. Материнская л. 2. только ед. такое же чувство, основанное на половом влечении; отношения двух лиц, взаимно связанных этим чувством. Несчастная л. Неразделенная л. Платоническая л. (см. платонический). Чувственная л. Пылать любовью. 3. перен. Человек, внушающий это чувство (разг.). Она была моей первой любовью. 4. только ед. склонность, расположение или влечение к чему-н. Л. к искусству. Л. к работе [20, с. 409].

В словаре Д. Н. Ушакова определены четыре основных ЛСВ лексемы любовь. Подобное определение даёт С. И. Ожегов: «Любовь, -ви, тв. -бовью, ж. 1. Чувство самоотверженной, сердечной привязанности. Л. к родине. Материнская л. Горячая л. Взаимная л. Он - моя первая л. (перен.: о человеке). 2. склонность, пристрастие к чему-н. Л. к музыке. Л. к искусству» [21, с. 440].

По мнению исследователя Е. В. Лобковой, в лингвокультурологическом аспекте «любовь по-русски», несмотря на происходящие в сознании современных но- 
сителей языка изменения, в основном духовная (при отрицательной оценке телесного), интенсивная, жертвенная. В общем, оценка любви представлена по-разному, но преобладает у русского народа положительная [1, с. 7].

Для выявления признаков концепта «любовь» в языковом сознании младшего школьника проведен опрос учащихся 2-4 классов г. Воронежа («любовь это ...»). В опросе приняло участие 257 респондентов. Результаты опроса позволяют нам выделить следующие составляющие концепта: 1) чувство самоотверженной, сердечной привязанности; 2) человек, внушающий это чувство; 3) склонность, пристрастие к чему-либо; 4) моральные качества.

Причем первая составляющая включает две части: чувство, основанное на половом влечении; отношения двух лиц, взаимно связанных этим чувством; чувства к родным, близким (семье). Рассмотрим полученные результаты.

\section{1. Чувство самоотверженной, сердечной привязанности}

Чувство, основанное на половом влечении; отношения двух лиц, взаимно связанных этим чувством: притяжение; обнимашки, объятия, поцелуи (2 класс - 17 \%); когда с первого взгляда тебе понравилась эта девушка; когда человек в кого-то влюблен; два человека понравились друг другу; когда человек смотрит в глаза и всегда думает о нем, и никогда не забывает; это два любящих человека, которые делают всё вместе, и готовы на всё, чтобы не разлучиться; это когда я встречаю свою половинку (3 класс - 23 \%); отношения девушки и парня; когда два человека влюбляются друг в друга. У них появляется семья, они доверяют друг другу; замечательное время с тем, кого любишь и с кем хочешь провести всё время жизни; чувство, которое объединяет любимых; когда два человека встречаются и всегда находятся вместе; когда человек встретил женщину, и она ему понравится по-настоящему; чувства между людьми и когда они женятся; когда человек идет за другим, готов отдать за него жизнь; когда ты понимаешь, что ты не можешь от кого-то оторвать взгляд; чувства человека, который очень счастлив; пара и поцелуйчики, и всё взаимно; взаимоотношения, теплота и боль (когда бросают) (рисунок сердечка) (4 класс - 30 \%).

Чувства к родным, близким (семье): я люблю маму и всех остальных; когда все вместе (2 класс - 4 \%); если ты кого-то любишь: маму, папу, бабушку, дедушку; когда я люблю свою семью, родителей; когда я люблю брата, сестру; мама любит папу, мама с папой любят тебя, а тебя любит бабушка, а ты любишь бабушку и дедушку, а дедушка любит тебя, а тебя любит сестра и брат, и ты любишь их тоже любишь, а тебя любит семья (3 класс - 23 \%); любишь папу и маму, сестру, брата и тебя тоже любят; любишь родственников; любить бабушку и дедушку, тетю, дядю; первое чувство, когда ты родился, ты сразу полюбил твою маму; первая любовь - это мама. Она заботится, чтобы тебе было лучше. Папа как мама, но он защитник семьи, а семья - это любовь (4 класс - 16 \%).

2. Человек, внушающий это чувство: мама; самый любимый человек в мире на всем свете!!! (2 класс - 4 \%).

3. Склонность, пристрастие к чему-либо: люблю кошку, собаку; торт; животных; чудеса, книжки; когда я люблю мороженое; когда тебе ставят 5/5; когда например, торт с орехами не любят, а торт без орехов любят; люблю цветы, учителя, день рождения, новый год (3 класс - $17 \%$ ); нравится какой-то предмет, например, нравится шерсть у игрушки, носик, глаза; любовь к животным; любовь бывает 
не только между людьми, но и между человеком и каким-либо предметом (любимая игрушка, чашка и т. д.); ты любишь своих питомщев; человек любит собак; какой-то у тебя любимый предмет (урок); любовь кразным занятиям (4 класс - 13 \%).

4. Моральные качества: ласка; доброта; помощь; не бросать в беде; забота; уважение (2 класс - $75 \%$ ); доброта; уважение забота; помощь; благодарность; нежность (3 класс - $37 \%$ ); добро; искренняя помощь близким; никогда не бросать любимого; уважение; доверие; взаимопонимание; забота о близком человеке (4 класс $-37 \%)$.

Единичные ответы: дарить цветы, конфеты, подарки (3 класс); это химический элемент, который заставляет размножаться всё живое; забота Бога (4 класс).

Таким образом, для учащихся 2 класса в приоритете составляющая «моральные качества» (75 \%), для учащихся 3-4 класса - «чувство самоотверженной, сердечной привязанности», причем первая ее часть (3 класс - 23 \%, 4 класс - 30 \%), на втором месте составляющая «моральные качества» (3 класс - 17 \%, 4 класс $13 \%)$.

Дети дают положительную оценку, определяя ценностную составляющую концепта: Любовь может сделать невозможное!!! Это ценность; любви много не бывает; любовь золотом не купишь; любовь нужно хранить; сердце должно быть наполненным любовью; я хочу, чтоб все любили друг друга; самая высокая любовь к нам идет от Иисуса Христа; Господь сама любовь; Бога тоже надо любить, и сердце любовью заполнится (2 класс); любовь для меня - это очень, очень, очень сильное и глубокое чувство. Она настолько сильная и глубокая, как самый большой в мире айсберг на планете! Любовь - это сердце навсегда (рисунок сердца) (3 класс); любовь дает радость (4 класс).

Как показывают отмеченные в материале респондентами ассоциативные образы и символы любви и влюбленных, они являются общими для людей разного возраста и разных народов (сердце).

Наше исследование также имело целью выявить признаки концепта, актуальные для современных младших школьников. Нами был проведен опрос учащихся 2-4 классов (198 человек) образовательных организаций г. Воронежа «любовь - какая...».

Информанты наделяют любовь признаками одушевлённого существа: добрая (2 класс - 19\%, 3 класс - 14\%, 4 класс - 19\%), нежная (2 класс - 10 \%, 3 класс - 5 \%, 4 класс - $19 \%$ ), милая (2 класс - 10 \%, 4 класс - 23 \%), ласковая (2 класс - 8 \%, 4 класс - 8 \%), сильная, умная, мудрая, верная, искренняя, добродушная, скромная, счастливая, сексуальная.

Можно отметить несколько общих высокочастотных ассоциаций: большая, добрая, красивая, крепкая, верная. При характеристике любви преобладают положительные коннотации: прекрасная, изумительная, неотразимая, милосердная, безграничная, романтическая, великолепная, бескорыстная, неописуемая, очаровательная, чудесная, волшебная, вечная, хотя имеются и негативные эмоциональные реакции: разбитая, ненастоящая, короткая, грустная. Таким образом, дети отмечают, что любовь дает людям не только счастье и радость, но и приносит страдания, что совпадает с мнениями взрослых [22]. Кроме того, составляющие концепта включают в себя полярные мнения: природа любви духовная (любовь к Родине; Бога тоже надо любить) / физиологическая (чувства 
между людьми, когда они женятся); любовь как естественное чувство (первое чувство, когда ты родился, ты сразу полюбил твою маму) / неестественное (когда человек идет за другим, готов отдать за него жизнь); уникально (безграничная) / повторимо (взаимоотношения, теплота и боль (когда бросают)); любовь вечна (Любовь - это сердце навсегда) и конечна (короткая).

Кроме того, в рамках исследования учащимся 3-4 класса было предложено в свободной форме высказать свое мнение о любви. Приведем некоторые ответы детей.

Любовь разная: кто-то любит книги, кто-то маму-папу, кто-то землю, а ктото и весь мир. Не бывает людей, которые что-то не любят. Все что-то любят! (Алиса, 2 класс)

Любовь - это счастье, доброта, жизнь. Любовь - это сердечко, наполненное любовью. С любовью мы живем. Мы любим всё, что нам нравится и что мы чувствуем дорогим для нас. Например, учительница, мама, родина, столица, дом, в котором мы живем, все родные, друзья. Любовь - это согласие, счастье, чувство. Я люблю всё! (Эльвира, 3 класс)

Любовь - это когда можно кому-нибудь помочь: животным в приютах, детям в детских домах. Любовь - это когда можно помочь маме (на кухне), папе в гараже, бабушке донести сумку до дома, перевести дедушку через дорогу... после этого, если ты заболел, тебе отплатят тем же. Любовь - это когда можно сохранить утку, шуку, бабочку, медведя, мышку, чтобы это вид не исчез как динозавры, а остался навсегда. Любовь - это когда делать плохого не надо. Не надо рубить деревья, чтобы наш мир не остался пустым. Вот такая это любовь!!! (Руслан, 3 класс)

Однажды я приехала к бабушке, у неё была собака. Когда первый день прошел, я легла спать. На следующее утро я пошла к собаке и увидела её не одну, она была со щенком. Я взяла его в руки и почувствовала, что такое любовь! Это чувство прекрасно! Любовь может быть к матери, к Родине, это чувство повсюду! Я люблю всё, что меня окружает! (Диана, 3 класс)

Любовь - это то, что в человеке есть с самого детства. Есть любовь искренняя, а есть лживая. Лживая любовь приходит с возрастом. А настоящая с самовыражением. Доброта и любовь - это самое главное! (Артем, 4 класс)

Любовь. Интересное слово. Каждый человек понимает его по-своему. Как выражают любовь? По-разному: словами, поступками, подарками или кто-то держит её в себе. Это может быть любовь к Родине, любовь к маме и папе, к любимому человеку, который всегда рядом. Люди любят каждый по-своему. Не бывает так, чтобы какое-то существо осталось без любимого им человека! (Вероника, 4 класс)

Это когда кто-то кого-то или что-то любит. Но никто не должен любить на словах! Нужно совершать дела или поступки, которые подтверждают любовь того человека. (Кирилл, 4 класс)

Это то, что нам дают родные и близкие, это дают нам тогда, когда человек ещё ребенок. Младенца любят, любят подростков, любят взрослых людей. Есть детская любовь - детям как бы дают её, а дети также учатся её давать. Есть взрослая любовь - это когда находишь человека с похожими качествами, с похожими любимыми вещами и так далее. Есть несколько типов любви: любовь с первого взгляда, есть, когда при стечении обстоятельств, бывает, помог в чем-то человеку, а потом 
встретил его. Любовь - многогранная вещь, которую не всегда можно почувствовать в душе. (Вадим, 4 класс)

Любовь я воспринимаю, когда человек очень тебя обожает, хочет поскорее встретиться, но не может, потому что он может от тебя далеко жить. Поэтому он может позвонить по видеосвязи. И он может тебя пригласить куда-нибудь погулять. А если начнётся дождь, то можно просто по телефону поговорить (Дарья, 4 класс)

Я очень люблю своих родителей. Я очень люблю одну девочку. Я дружу с Кириллом. Мой любимый питомец - это моя кошка Зина. Всё!!!

Но не всё. Я очень люблю держать винтовку Мосина и ППШ. Я люблю пирожное, мороженое, пирог, конфету. Я люблю много чего! (Максим, 3 класс).

Таким образом, концепт «любовь», наряду с концептами «совесть», «душа» [23] является важнейшей составляющей языковой картины мира младшего школьника. Исследование демонстрирует возрастную и национальную специфику изучаемого феномена. В ответах детей достаточно полно отразилось коллективное языковое сознание, однако имеется такая составляющая концепта, как «моральные качества», что является возрастной особенностью концепта «любовь», присущей детям данного возраста.

\section{Ссылки / References}

1. Лобкова Е. В. Образ-концепт «любовь» в русской языковой картине мира: автореф. дис. ... канд. филол. наук. Омск, 2005. 19 с.

2. Можейко М. А. Любовь // Новейший философский словарь. Минск, 1999. С. 383-397.

3. Мягкова Е. Ю. Эмоционально-чувственный компонент значения слова: дис. ... канд. филол. наук. Курск, 2000. 247 с.

4. Шаховский В. И. Эмоциональные культурные концепты: параллели и контрасты // Языковая личность: культурные концепты: Сборник научных трудов. ВолгоградАрхангельск, 1996. С. 80-96.

5. Воркачёв С. Г. Концепт любви в русском языковом сознании // Коммуникативные исследования 2003: Современная антология / под ред. проф. О. А. Леонтович. Волгоград, 2003. С. 189-207.

6. Нагапетян К. Ж. Основополагающее значение концепта «любовь» в русской культуре // Молодой ученый. 2016. № 20 (124). C. 837-839. URL:

https://moluch.ru/archive/124/34208/ (дата обращения: 09.04.2020).

7. Арутюнова Н. Д. Язык и мир человека. М.: Языки русской культуры, 1999. 896 с.

8. Воркачёв С. Г. Концепт счастья в русском языковом сознании: опыт лингвокультурологического анализа. Краснодар, 2002. 142 с.

9. Алефиренко Н. Ф. Поэтическая энергия слова. Синергетика языка, сознания и культуры. М.: Academia, 2002. 391 с.

10. Гольдин В. Е. Проблема варьирования культурных концептов // Проблемы вербализации концептов в семантике языка и текста. Ч. 1. Волгоград, 2003. С. 80-86. 
11. Гоннова Т. В. Социокультурные характеристики концепта «труд» в русском языковом сознании: автореф. дис. ... канд. филол. наук. Волгоград, 2003. 20 с.

12. Карасик В. И. Языковой круг: личность, концепты, дискурс. М., 2004. 447 с.

13. Красных В. В. «Свой» среди «чужих»: миф или реальность? М., 2003. 375 с.

14. Степанов Ю. С. Константы. Словарь русской культуры. Опыт исследования. М.: Школа. Языки русской культуры, 1997. 824 с.

15. Воркачёв С. Г. Концепт счастья: понятийный и образный компоненты // ИАН СЛЯ. 2001. T. 60. № 6. C. 47-58.

16. Воркачёв С. Г. Любовь как лигвокультурный концепт М.: Гнозис, 2007. 285 с.

17. Федеральный государственный образовательный стандарт начального общего образования. М.: Просвещение, 2018. 52 с.

18. Философский энциклопедический словарь / Гл. ред. Л. Ф. Ильичев, П. Н. Федосеев, С. М. Ковалев, В. Г. Панов. М.: Сов. Энциклопедия, 1983. 840 с.

19. Психологический словарь / Под общ. ред. А. В. Петровского, М. Г. Ярошевского. 2-е изд., испр. и доп. М., 1990. 494 с.

20. Большой толковый словарь русского языка / Под ред. Д. Н. Ушакова. М.: Аст: Астрель, 2008. 1268 c.

21. Ожегов С. И. Словарь русского языка / Под общ. ред. проф. Л. И. Скворцова. 25-е изд., испр, и доп. М.: 000 «Издательство Оникс», 2008. 1328 с.

22. Яськова А. В. Концепт «любовь» в русской и китайской языковых картинах мира // Территория новых возможностей. Вестник Владивостокского государственного университета экономики и сервиса. 2017. Т. 9. № 1. С. 237-245.

23. Лемяскина Н. А. Значимые константы культуры в языковой картине мира младшего школьника // Вестник ВГУ, серия Лингвистика и межкультурная коммуникация. 2018. № 4. Воронеж: ВГУ, С. 94-96. 